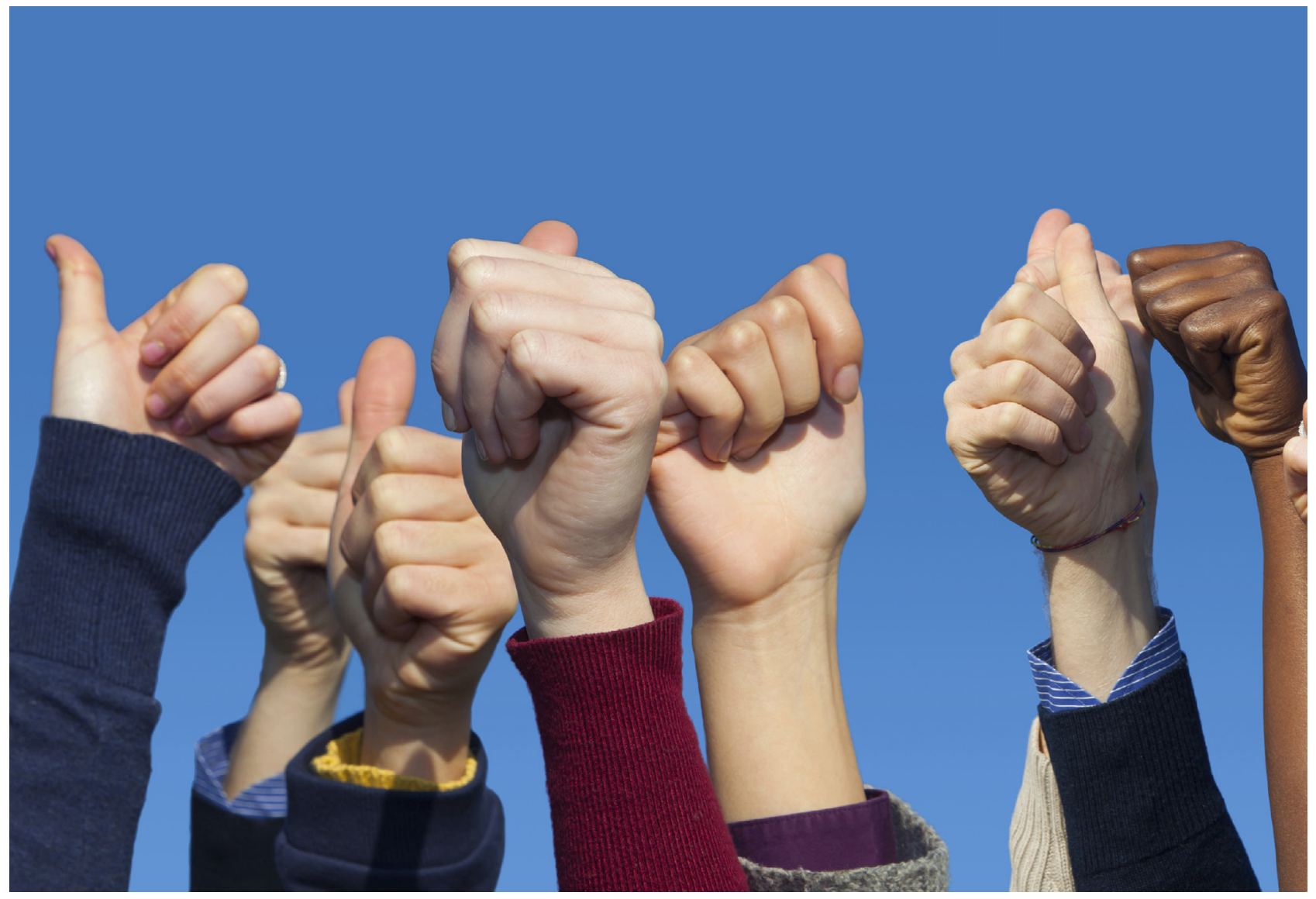

\title{
QUANTO MAIS \\ DIVERSIDADE, MELHOR!
}

FGV/EAESP REALIZA AÇÕES PARA ATRAIR ALUNOS DE DIFERENTES REGIÕES E CONDIÇÕES SOCIOECONÔMICAS.

| POR ALINE LILIAN DOS SANTOS

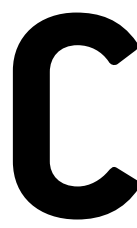

onsiderando a importância da pluralidade no ambiente de ensino para promover um aprendizado mais rico e heterogêneo, a EAESP está empenhando esforços para ampliar a diversidade entre seus alunos.
De acordo com Fernando Abrucio, coordenador da graduação em Administração Pública, ações que visam atrair estudantes de diferentes regiões e condições socioeconômicas estão sendo realizadas na instituição: "A Escola está ampliando o número de lugares onde aplica o vestibular, agora são 15 
cidades em todo o país. Também estamos fazendo uma campanha em escolas públicas - estimulando os alunos a prestarem o vestibular - e temos aumentado o número de bolsas para estudantes com necessidades socioeconômicas, além de destinar algumas vagas para o ENEM".

Essas medidas também devem ser ampliadas para o âmbito internacional, já que no próximo processo seletivo haverá vagas para estudantes estrangeiros, os quais não serão intercambistas, mas farão o curso integralmente na EAESP.

\section{PORTAS ABERTAS AOS TALENTOS}

Considerando que a intenção da EAESP é atrair talentos de diferentes classes sociais e regiões, a Escola tem reforçado a ideia de que qualquer aluno pode estudar na instituição, mesmo sob dificuldades financeiras, já que há grandes chances de ele conseguir uma bolsa. "A imagem de que era impossível fazer GV, de que era algo inalcançável, está mudando", diz Abrucio.

Dessa forma, as ações citadas têm gerado resultados positivos para a instituição. "Este ano recebemos alunos de Goiânia, Campo Grande, Cuiabá, Rio Grande do Sul... e a tendência é que isso evolua cada vez mais rápido. Quanto mais alunos de fora de São Paulo e de escolas públicas, melhor do ponto de vista da diversidade", afirma o coordenador.

\section{BENEFÍCIOS PARA O APRENDIZADO}

Outro ponto relevante é que essa iniciativa beneficia não apenas os alunos que ingressam na instituição, mas também seus graduandos e professores, contribuindo para a maior troca de experiências e um aprendizado mais rico. "Quando falamos em formar líderes para transformar o Brasil, precisamos conhecer o país. Se você não tem contato com o diverso, seu poder de liderança é muito questionável. O diálogo com pessoas de diferentes realidades é essencial para o cumprimento da nossa missão", diz André Carvalho, vice-coordenador da graduação em Administração de Empresas.

Abrucio completa ressaltando como a multiplicidade de pontos de vista colabora para uma discussão mais ampla: "A diversidade te dá a capacidade de gerar um debate muito mais rico. Ela, sem dúvida, torna o curso muito mais interessante".

\section{ALUNOS ABRAÇAM A CAUSA}

Além das iniciativas da Escola, os alunos da EAESP também têm desenvolvido projetos com o mesmo fim. É o caso do "GV Day", como explica André: "Além do Dia FGV, uma ação institucional aberta ao público para apresentar os cursos, temos o GV Day, em que os alunos promovem atividades com os estudantes visitantes, os quais podem assistir a palestras, conversar com as entidades e perguntar para os próprios alunos da GV: 'Por que eu devo vir para cá?'”.

Outro projeto que tem beneficiado muitas pessoas é o Cursinho FGV. Criado pelos alunos em 2013, ele oferece aulas gratuitas para estudantes de baixa renda que querem ingressar na instituição. "Buscamos desenvolver ferramentas didáticas e pedagógicas para superar os gaps que os alunos trazem da educação básica. É possível tornar a largada mais parecida para todos os que sonham estudar na FGV", afirma Daniel Cordeiro, diretor pedagógico do cursinho pré-vestibular.

Destinado para quem deseja cursar Administração de Empresas, Administração Pública ou Direito, sua taxa de aprovação tem aumentado a cada semestre: "Até hoje, 22 alunos foram aprovados, sendo que 13 ingressaram no último vestibular, além dos que entraram em outras faculdades de renome", conta Amanda Sadalla, membro do Conselho Diretivo da entidade.

O cursinho também oferece benefícios como: material escolar, auxílio-alimentação e transporte, que são financiados por parceiros como Grupo Pão de Açúcar, Fundação Bradesco e CPV educacional. "Esse suporte me permitiu frequentar todas as aulas, pois apenas com a renda da minha família não seria possível arcar com esses custos", revela Tania Otho, ex-aluna de escola pública e aprovada no último vestibular da FGV.

Além disso, os alunos recebem acompanhamento pedagógico e psicológico para potencializar o seu desenvolvimento. "A iniciativa é maravilhosa! Aprendi muita coisa que não tive na escola e vi a oportunidade de passar no vestibular. O cursinho me levou ao lugar que sempre sonhei", conta Thales Vieira, também ex-aluno de colégio público e que ingressou na EAESP. Ele completa dizendo que buscou outros cursinhos gratuitos, mas nenhum the concedeu uma bolsa que atendesse às suas necessidades.

O processo seletivo envolve uma prova de conhecimentos gerais, habilidades de interpretação e raciocínio lógico, além de um questionário socioeconômico e avaliação do perfil do candidato. As aulas são ministradas voluntariamente por alunos de graduação e pós-graduação da FGV, e acontecem aos sábados, das $8 \mathrm{~h}$ às $18 \mathrm{~h}$, na própria Escola. Para mais informações: cursinhofgv.com

ALINE LILIAN DOS SANTOS > Jornalista da GV-executivo > aline.lilian@fgv.br 